\title{
VOCATIONAL INTERESTS, PERSONALITY AND EFFECTIVE POLICE PERFORMANCE
}

\author{
JOHN A. JOHNSON AND ROBERT HOGAN
}

The Johns H'pkins University

\begin{abstract}
Scores on vocational interest inventories are commonly thought to be unrelated to job performance. A close examination of the literature suggests, however, that vocational scales other than those describing the occupational group in question may often predict job performance. A case in point is reported here, using Holland's Self Directed Search and two groups of policemen. Scores on the Artistic and Conventional scales consistently predict effective performance as a patrolman in this Realistic and Social occupation.
\end{abstract}

CONVENTIONAL wisdom in the field of vocational psychology tells us that vocational interest inventories rarely predict work performance (cf. Strong, 1943, pp. 13-16). In fact, conspicuous warnings to that effect often accompany instructions for interpreting a client's test results. Given that vocational interests are linked to personality variables such as temperament and interpersonal style (Costa, Fozard, and McCrae, 1977), and personality is related to vocational success (e.g., Harrell, 1972), it is somewhat surprising to find that interest inventories do not predict work performance.

Muchinsky and Hoyt (1974) attribute this apparent paradox to the methodology of previous research. In Muchinsky and Hoyt's own study, engineers were scored on the Group II (science and engineering) and Group V (social service) scales of the Strong Vocational Interest Blank when they were still in school. Correlations several years later between these scales and criteria of work performance were small (.20 to .30) and nonsignificant except those between Group V scores and self- and peer-ratings. Muchinsky and Hoyt stress that very

\footnotetext{
Send reprint requests to Robert Hogan, Department of Psychology, The Johns Hopkins University, 34th and Charles Streets, Baltimore, Maryland 21218. We thank Chief Cornelius Behan and his staff of the Baltimore County Police for their cooperation in the course of this research.
}

Copyright $(1981$ by Personnel Psychology, Inc. 
few of these engineers had high Group V (social service) scores; one might conclude from this that scores on scales that define a person's occupation will not predict work performance, but scores on other scales may indicate personality characteristics less common to the group but which lead to superior work performance. A number of studies reviewed by Campbell (1971, p. 64) seem to support this contention.

We tested this hypothesis-that scores on scales other than those describing the occupational group in question predict success within that group - with two groups of police officers, using Holland's (1973) Self Directed Search (SDS). There are no published investigations of the SDS's relation to work performance.

Holland (1973) originally described police as Realistic with a secondary Social component; he has since re-classified this group as primarily Social and secondarily Realistic, although Holland (personal communication) reports that mean scores on these scales have been nearly identical in all of the police he has tested. In any case, these scales were not expected to predict performance as a policeman. The variables that were hypothesized to relate to performance were the Artistic and Conventional scales of the SDS, because the personality characteristics associated with these types seem to be relevant to effective police performance. The conforming, orderly, persistent, and selfcontrolled tendencies of the Conventional type would appear to be more conducive to good police work than the emotional, impulsive, nonconforming tendencies of the Artistic type.

\section{Method}

Two samples were used in this study. The first consisted of 50 police officers from an affluent Baltimore suburb who had been on the force for one to four years. All were high school graduates ( 20 had attended college), and most were from working class families. The sample contained 38 white males, 2 black males, 9 white females, and 1 black female.

The second sample contained 36 white male and 2 white female police cadets who were attending this department's police academy at the time of testing. The sample was similar to the first in terms of education and social class background.

Both groups were administered Holland's (1973) Self Directed Search as part of a project designed to improve police selection procedures. All subjects were rated by two supervisors for overall performance as police officers using the rating form developed by Dunnette and Motowidlo (Note 2). The reliability of these ratings (inter-rater correlations) in the first sample was .92; in the second sample, it was 
82. Additional criteria were available for the first sample: final grades at the police academy, the number of spontaneous complimentary or appreciative letters in their personnel file, and the number of spontaneous complaint letters in their personnel file. Correlation coefficients between subjects' scores on the SDS and these criterion measures were computed.

\section{Results and Discussion}

A summary of the results is shown in Table 1. Both groups received their highest scores on the Realistic and Social scales. In the first sample, the third highest score was on the Enterprising scale; in the second sample, Enterprising and Investigative scale scores were essentially tied as the third highest. These findings support Holland's description of a policeman as an RSE or SRE type.

As in previous studies, the magnitude of the correlations between the vocational scales and the criterion scores are small (.10 to .30). The Social and Enterprising scales were significantly correlated with appreciative and complaint letters in the first sample. This is reasonable because the Social and Enterprising types represent Holland's two extraverted types (cf. Holland, 1973; Hogan and Johnson, Note 1), and extraverts probably tend to become more personally involved with the public and hence elicit more public response (both good and bad).

With regard to the major point of this study, the Artistic and Conventional scales correlated significantly with the criteria in both groups. The Artistic scale correlated in the predicted direction with academy grades $(-.29, \mathrm{p}<.05)$ and complaint letters $(.34, p<.01)$ in the police officer sample, and with supervisor ratings $(-.22, p<.10)$ in the cadet sample. The Conventional scale correlated in the predicted direction with academy grades $(.21, p<.10)$ in the police officer sample, and with supervisor ratings $(.23, p<.10)$ in the cadet sample.

These results reinforce Campbell's assertion that differential success in one occupation may be related to vocational scale scores for other occupations. In the present study the Realistic and Social scales (which form the Holland code for Policeman) were not consistently related to police effectiveness, but the Artistic and Conventional scales were correlated with performance.

The explanation for this phenomenon is both statistical and theoretical. First, because most policemen will score relatively high on the Realistic and Social scales, the variance is restricted, making these scales poor predictors.

Second, examination of factor analyses of Holland's Vocational Preference Inventory and Self Directed Search (e.g., Edwards and Whitney, 1972) led Hogan and Johnson (Note 1) to conclude that the 
TABLE 1

50 Police Officers

\begin{tabular}{|c|c|c|c|c|c|c|c|c|c|c|c|c|}
\hline Measure & Mean & $\mathrm{SD}$ & $\mathbf{R}$ & I & A & $\mathbf{S}$ & Pearson & Correlatic & $\begin{array}{l}\text { Coefficie } \\
\text { Super- } \\
\text { visor } \\
\text { Ratings }\end{array}$ & $\begin{array}{l}\text { Acad- } \\
\text { emy } \\
\text { Grades }\end{array}$ & $\begin{array}{l}\text { Appreci- } \\
\text { ative } \\
\text { Letters }\end{array}$ & $\begin{array}{l}\text { Compliant } \\
\text { Letters }\end{array}$ \\
\hline \multicolumn{13}{|l|}{ SDS Scale } \\
\hline Realistic (R) & 32.3 & 10.4 & - & $22 *$ & 08 & 04 & 10 & 01 & 18 & -17 & 01 & 14 \\
\hline Investigative (I) & 23.5 & 9.0 & & - & $33^{* *}$ & $32 * *$ & $39^{* * *}$ & $25^{* *}$ & -07 & 06 & 03 & 15 \\
\hline Artistic (A) & 19.0 & 11.2 & & & - & $46^{* * *}$ & $35^{* * *}$ & 01 & -08 & $-29 * *$ & -16 & $34^{* *}$ \\
\hline Enterprising (E) & 27.9 & 8.5 & & & & & - & $34^{* * *}$ & -01 & 05 & $22^{*}$ & 17 \\
\hline Conventional (C) & 22.4 & 12.0 & & & & & & - & 15 & $21^{*}$ & -05 & -08 \\
\hline \multicolumn{13}{|l|}{ Criteria } \\
\hline Ratings & 6.5 & 2.0 & & & & & & & - & $42 * * *$ & $26^{* *}$ & $-23^{*}$ \\
\hline Grades & 84.0 & 8.5 & & & & & & & & - & 03 & $-58^{* * *}$ \\
\hline Appreciation & 2.7 & 2.5 & & & & & & & & & - & 08 \\
\hline Complaints & 0.5 & 1.0 & & & & & & & & & & - \\
\hline \multicolumn{13}{|c|}{38 Police Cadets } \\
\hline & & & & & & & Pearson & Correlatic & $\begin{array}{c}\text { Coefficie } \\
\text { Super- } \\
\text { visor }\end{array}$ & & & \\
\hline Measure & Mean & $\mathrm{SD}$ & $\mathbf{R}$ & I & $A$ & $S$ & $\mathrm{E}$ & $\mathrm{C}$ & Ratings & & & \\
\hline \multicolumn{13}{|l|}{ SDS Scale } \\
\hline Realistic (R) & 34.2 & 8.7 & - & $48^{* * *}$ & 04 & $29^{* *}$ & $37^{* *}$ & 13 & -07 & & & \\
\hline Investigative (I) & 27.4 & 9.3 & & - & $45^{* * *}$ & $50^{* * *}$ & $43^{* * *}$ & $50^{* * *}$ & -17 & & & \\
\hline Artistic (A) & 18.9 & 10.0 & & & - & $55^{* * *}$ & $32^{* *}$ & $30^{* *}$ & $-22 *$ & & & \\
\hline Social (S) & 32.4 & 8.3 & & & & - & $79 * * *$ & $59^{* * *}$ & -05 & & & \\
\hline Enterprising (E) & 27.2 & 9.8 & & & & & - & $65^{* * *}$ & 01 & & & \\
\hline Conventional (C) & 22.4 & 9.2 & & & & & & - & $23^{*}$ & & & \\
\hline \multicolumn{13}{|l|}{ Criterion } \\
\hline Ratings & 5.0 & 1.2 & & & & & & & - & & & \\
\hline
\end{tabular}

Note,-Decimal points from correlation coefficients are omitted.

$* p<.10$.

$* * p<.05$.

$* * * 0.01$

(all one-tailed tests) 
Artistic and Conventional types define a personality dimension that Block and Block (1979) call ego control. High ego control, according to Block and Block, entails delay of gratification, cautiousness, perseveration, conformity, and the ability to concentrate and organize. This closely resembles Holland's description of the Conventional type, who is conforming, inhibited, orderly, persistent, and self-controlled.

Low ego control, on the other hand, includes impulsivity, emotional expressiveness, distractability, a tendency to seek stimulation, disregard for social customs and mores, and a tendency to respond to events in novel and original ways. This also describes the Artistic type, who is emotional, imaginative, impulsive, nonconforming, and original. It appears then, that the Artistic and Conventional scales not only carry more statistical variance, but also point to a personality construct-ego control - that is both practically and theoretically significant for police work.

\section{REFERENCE NOTES}

1. Hogan, R. and Johnson, J. A. The Hopkins Personality Inventory: A socioanalytic view of the structure of personality. Unpublished manuscript, The Johns Hopkins University, 1979.

2. Dunnette, M. D. and Motowidlo, S. J. Development of a personnel selection and career assessment system for police officers in patrol, investigative, supervisory, and command positions. Prepared for the Department of Justice, Law Enforcement Assistance Administration, National Institute of Law Enforcement and Criminal Justice. Available from Personnel Decisions, Inc., 2300 Foshay Tower, Minneapolis, Minnesota 55402 .

\section{REFERENCES}

Block, J. H. and Block, J. The role of ego-control and ego-resiliency in the organization of behavior. In W. A. Collings (Ed.), Minnesota Symposia on Child Psychology, Volume 13. New York: Lawrence Erlbaum, 1979.

Campbell, D. P. Handbook for the Strong Vocational Interest Blank. Stanford: Stanford University press, 1971.

Costa, P. T. Jr., Fozard, J. L., and McCrae, R. R. Personological interpretation of factors from the Strong Vocational Interest Blank. Journal of Vocational Behavior, 1977, $10,231-243$.

Edwards, K. J. and Whitney, D. R. A structural analysis of Holland's personality types using factor and configurational analysis. Journal of Counseling Psychology, 1972, 19, 136-145.

Harrell, T. W. High earning MBA's. PERsonnel PSYCHOLOGY, 1972, 25, 523-530.

Holland, J. L. Making vocational choices: $A$ theory of careers. Englewood Cliffs, New Jersey: Prentice-Hall, 1973.

Muchinsky, P. M. and Hoyt, D. P. Predicting vocational performance of engineers from selected vocational interest, personality, and scholastic aptitude variables. Journal of Vocational Behavior, 1974, 5, 115-123.

Strong, E. K. Jr. Vocational interests of men and women. Stanford: Stanford University Press, 1943. 